старший науковий співробітник відділу навчання жестової мови Інституту спеціальної педагогіки і психології імені Миколи Ярмаченка Національної академії педагогічних наук України (Київ, Україна)natbor07@gmail.com

\title{
ІННОВАЦІЇ ОЦІНЮВАННЯ РІВНЯ СФОРМОВАНОСТІ ПРОФЕСІЙНОЇ КОМПЕТЕНТНОСТІ ПЕРЕКЛАДАЧІВ ЖЕСТОВОЇ МОВИ
}

У статті розглянуто питання щчодо збільшення кількості перекладачів жестової мови в Украйні завдяки Украӥнському товариству глухих. Втім, стала перевірка рівня сформованості професійної компетентності перекладачів жестової мови за екзаменаційною формою в паперовому форматі не відповідає викликам часу, оскільки не забезпечує підтримку лінгвістичних прав глухих, бо стара школа викладання до уваги брала якість перекладу калькованого жестового мовлення, а не власне якість української жестової мови.

Акцентовано увагу на розробленні й апробаџії інноваційного оцінювання жестомовної комунікативної компетентності перекладачів жестової мови, зокрема, освітньої сфери, яка була проведена за допомогою комп'ютерних технологій. Зазначено, щз розробниками комп'ютерної програми є представники СОDА, дидактичним забезпеченням програми займалися носії жестової мови.

Розглянуто, щзо апробація за інновачійною формою оиінювання рівня сформованості професійної компетентності перекладачів проходила за груповою формою (за кордоном діють також ординарна й бінарна форми перевірки професійних вмінь). Зазначено, з якою професійною категорією були допущені до сучасної атестацї освітні перекладачі жестової мови. Розкрито умови проходження перевірки на професійний рівень $і$ спеціально розроблені завдання з використанням комп 'ютерних технологій, які були поділені на блоки. Опрацьовано зміст блоків завдань, які характеризують різні форми й види перекладу між украӥнською мовою та украӥнською жестовою мовою.

Вивчено результати проходження інновачійної перевірки й проаналізовано групи помилок, допущених перекладачами жестової мови. Підкреслено, щуо в порівнянні з перекладачами жестової мови інших сфер діяльності освітні перекладачі жестової мови мали кращі результати, втім, вони були нижчими за очікувані. Наголошено $з$ доведенням, щзо інновація оцінювання професійної компетентності освітніх перекладачів засвідчила низький для роботи в освітній сфері рівень жестомовної комунікативної компетентності, щзо передбачає зміну змісту форм навчання та підвищення кваліфікації освітніх перекладачів жестової мови.

У статті подано діаграми й табличя результатів апробаиії оцінювання рівня сформованості професійної компетентності перекладачів жестової мови.

Ключові слова: апробація, блокова система завдань, комп'ютерна програма, освітні перекладачі жестової мови, результати оцінювання.

\section{Nataliia ADAMIUK, orcid.org/0000-0002-4927-6257 \\ Candidate of Pedagogical Sciences, \\ Senior Researcher at the Department of Sign Language Education of Mykola Yarmachenko Institute of Special Pedagogy and Psychology of the National Academy of Pedagogical Sciences of Ukraine (Kyiv, Ukraine)natbor07@gmail.com}

\section{INNOVATIONS FOR ASSESSING THE LEVEL OF FORMATION OF THE PROFESSIONAL COMPETENCE OF SIGN LANGUAGE TRANSLATORS}

The article raises questions about the increase in the number of sign language translators in Ukraine thanks to the Ukrainian Deaf Society. However, the old test of the level of formation of professional competence of sign language translators in the form of tickets does not meet the challenges of the time. Because it does not provide support for the linguistic rights of the deaf, because the old school of teaching took into account the quality of translation of calcified sign language, rather than the actual Ukrainian sign language.

Attention is focused on the development and testing of innovative assessment of gestural communicative competence of sign language translators, in particular the educational sphere, which was carried out using computer technology. It is stated that the developers of the computer program are representatives of CODA, didactic speakers of the program are engaged in native speakers. 
It was informed that the testing of the innovative form of assessing the level of professional competence of translators was carried out in a group form. Abroad, there are also simple and binary forms of testing professional skills. It is indicated with which the professional category educational sign language translators were admitted to the modern certification. The conditions for passing the test at a professional level and specially-designed tasks using computer technologies, which were divided into blocks, are disclosed. The content of task blocks characterizing different forms and types of translation between Ukrainian language and Ukrainian sign language is revealed. The results of the innovative testing are examined and the groups of mistakes made by sign language translators are analyzed. It was emphasized that in comparison with sign language translators of other fields of activity, educational sign language translators had better results, however, they were lower than expected. It was noted with proof that the innovation of assessing the professional competence of educational translators showed a low level of sign and communicative competence for work in the educational field, which implies a change in the content of training forms and advanced training of educational sign language translators.

The article presents diagrams and a table of the results of testing the assessment of the level of formation of the professional competence of sign language translators.

Key words: testing, block task system, computer program, sign language educational translators, evaluation results.

Постановка проблеми. Мовні права глухих осіб, тобто вільне використання у своїй життєдіяльності жестової мови (далі - ЖМ) як засобу спілкування, навчання тощо гарантовані Загальною декларацією прав людини ООН, Конвенцією ООН про права осіб 3 інвалідністю та іншими міжнародними й національними документами (Брюссельська декларація, 2010; Закон України, 2013; Конвенція, 2013; Резолюція, 1998; Стандартні правила, 1993). Разом із тим декларується їхне право на повний доступ до інформації й шляхом використання послуг професійних перекладачів ЖМ.

Кількість перекладачів ЖМ в Україні збільшується завдяки лобіюванню та захисту інтересів глухих громадян України Українським товариством глухих (далі - УТОГ) і виконанням державою своїх зобов'язань у частині соціального захисту громадян 3 інвалідністю. Підготовкою перекладачів ЖМ і підвищенням їхньої кваліфікації займається лише одна громадська організація - УТОГ: наявність ліцензованого посвідчення перекладача ЖМ підкріплюється практичними знаннями самих слухачів курсів і фактичним наданням ними перекладацьких послуг у різних сферах діяльності глухих осіб.

Втім, доводиться констатувати факт недосконалості наявних програм підготовки перекладачів ЖМ, що ставить під загрозу дотримання лінгвістичних прав глухих. Недосконалість програми навчання, короткий термін навчання, низька кваліфікація викладачів - лише деякі причини низького рівня жестомовної комунікативної компетентності (далі-ЖКК) перекладачів ЖМ. Основною проблемою є об'єктивне оцінювання фахової компетентності перекладачів ЖМ, оскільки варто мати чітку картину недоліків, які $€$ в програмі навчання, і зосередити увагу на якісній підготовці фахівців, які надають перекладацькі послуги особам з інвалідністю зі слуху.

Разом із тим важливим і відкритим питанням залишається форма, якість і ефективність перевірки рівня ЖКК перекладачів ЖМ. Зокрема, освітніх, оскільки від кваліфікації перекладачів ЖМ освітньої сфери залежить вільний доступ до вищої освіти й отримання повноцінної вищої освіти глухими особами.
Аналіз досліджень. Питання дослідження ЖМ розглядалося багатьма зарубіжними науковцями (W. Stokoe, D. Casterline, C. Croneberg, D. Boyes Bray, R. Sutton-Spence, B. Woll, S. K. Liddell, T. Papaspiro), які ставили на один рівень жестові q словесні мови (далі - CM) у питанні повноцінності; з питання жестового перекладу, підготовки перекладачів ЖМ увагу надавали O. Crasborn, T. Bloem, R. Dean, R. Pollard, D. Hermans, R. Van Dijk, I. Christoffels, T. Janzen, D. Korpiniski, J. Napier, R. Barker, A. Stratiy, M. de Wit. Серед українських дослідників ЖМ, які досліджують національну ЖМ, виділяються Н. Б. Адамюк, О. А. Дробот, А. В. Замша, О. Ф. Федоренко, I. I. Чепчина (2009-2019 роки) (Адамюк, 2017; Адамюк, 2012; Адамюк, Чепчина, 2008; Адамюк та ін., 2019; Адамюк та ін., 2018). Слід зазначити, що в процес перевірки рівня ЖКК перекладачів ЖМ активно включаються носії ЖМ та працівники Центрального правління УТОГ (В. В. Кириченко, Н. О. Ткач, І. І. Чепчина).

Мета статті. Метою статті $\epsilon$ відбиття результатів апробації інноваційної перевірки ЖКК перекладачів ЖМ освітньої сфери, яка була проведена за допомогою комп'ютерних технологій.

Виклад основного матеріалу. Розробниками комп'ютерної програми перевірки фахової майстерності перекладачів ЖМ є представники CODA, тобто чуючі особи, які були виплекані глухими батьками чи родичами та які перейняли унікальну культурну й мовну самобутність Глухих (Deaf), - P. О. Татарінов i I. B. Татарінова, фахові програмісти й знавці-практики української жестової мови (далі - УЖМ). Укладачем дидактичного забезпечення $\epsilon$ автор цієї статті 3 командою підтримки в особі I. В. Бондаренка, перекладача ЖМ, та В. В. Кириченко, носія ЖМ. Кількість експертів на перевірку рівня ЖКК перекладачів ЖМ становить 8 осіб із різних регіонів України: 3-поміж носіїв ЖМ і чуючих освітян і науковців (до функцій останніх відноситься перевірка граматики СМ). Для дотримання конфіденційності імена експертів не розголошуються. 
Метою апробації інноваційної перевірки кваліфікації перекладачів ЖМ засобом сучасних комп’ютерних технологій $€$ незалежне, неупереджене й всебічне оцінювання рівня ЖКК фахівців перекладу із ЖМ на СМ і навпаки. Ідея апробації полягає в зміні старих підходів оцінювання ЖКК, які не передбачають перевірку знань і практичних вмінь саме ЖМ, бо фактично об'єктом перевірки було кальковане жестове мовлення (далі - КЖм), яке є прообразом СМ, оскільки воно дотримується іiї мовних норм. Окрім того, важливим аспектом є максимальне наближення рівня ЖКК перекладачів ЖМ до рівня ЖКК самих носіїв ЖМ.

Використання комп'ютерної програми для перевірки й оцінювання ЖКК перекладачів ЖМ є новою сторінкою для України, де традиційною формою перевірки професійних компетентностей були білети в паперовому форматі. За кордоном комп'ютерна перевірка ЖКК $є$ вже сталою традиційною формою. Там розрізняють три види перевірки у частині іï кількісного проходження атестованими: ординарна (Фото № 1), бінарна (Фото № 2) і групова (Фото № 3).

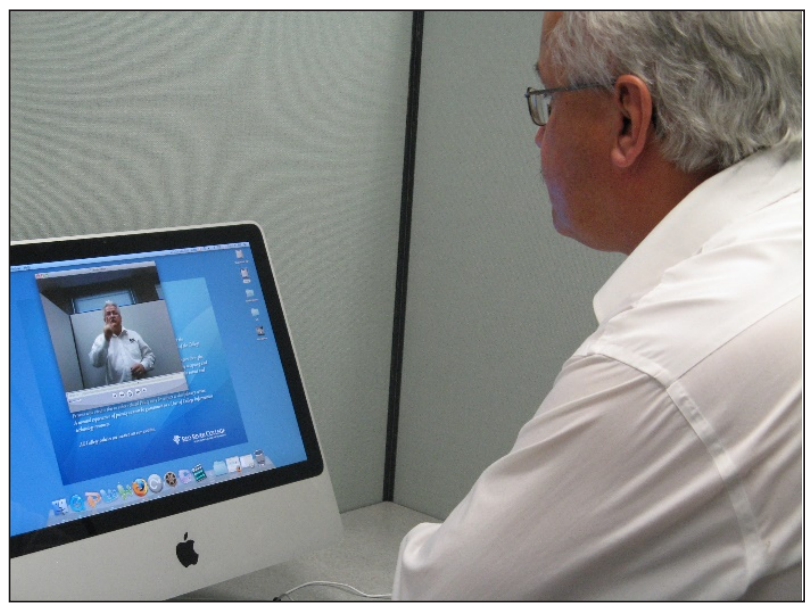

Фото 1. Ординарна форма атестації

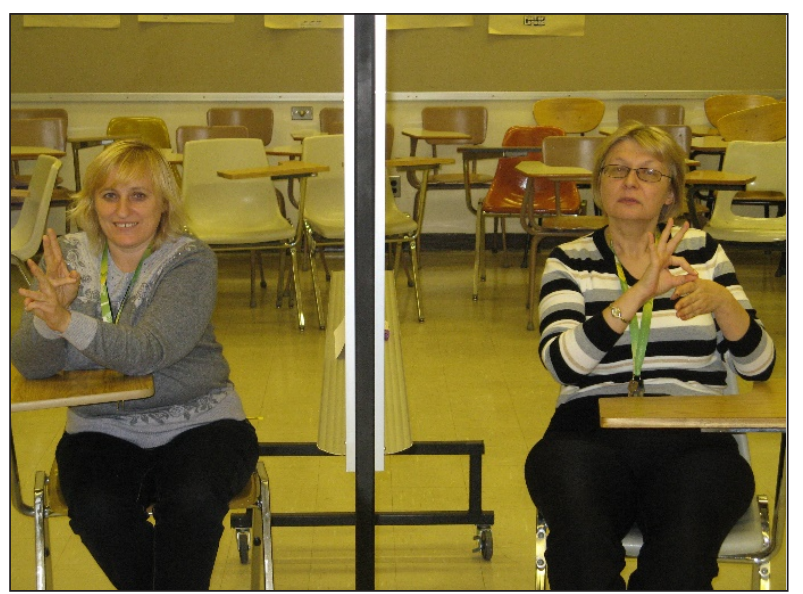

Фото 2. Бінарна форма атестації

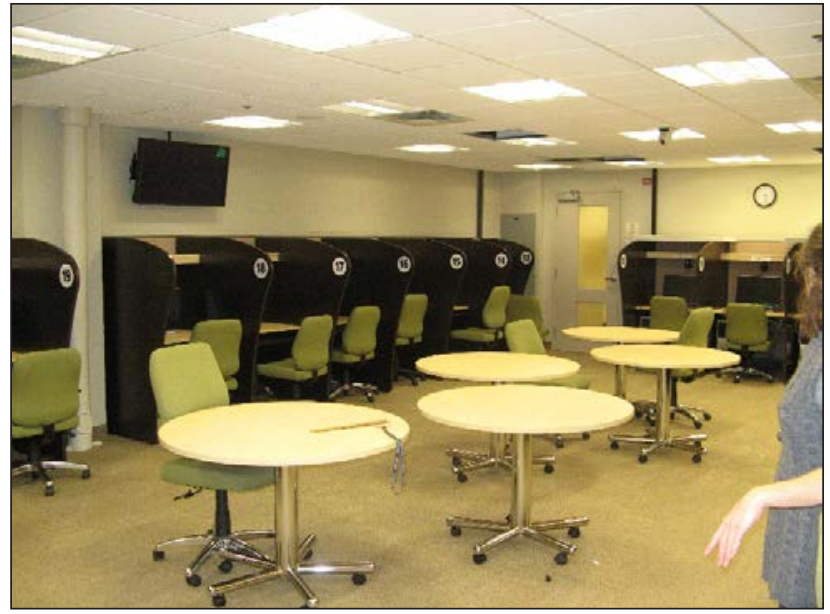

Фото 3. Групова форма атестації

Перша апробація оцінювання рівня ЖКК перекладачів засобом комп'ютерних технологій була проведена в жовтні 2016 року в облаштованому приміщенні центрального правління УТОГ, тому атестація центральна. До іï проходження були допущені перекладачі ЖМ, які мали освітньокваліфікаційний рівень «перекладач ЖМ першої категорії» та «перекладач ЖМ вищої категорії» та які мали в плановому порядку проходити чергову атестацію саме у 2016 році. Оскільки були претенденти на отримання першої категорії з-поміж перекладачів ЖМ другої категорії, то вони теж були допущені до атестації. Також була одна особа $з$ достатнім рівнем ЖКК, яка за рішенням центральної атестаційної комісії (далі - ЦАК) допускалася до атестації: виконуючи функції перекладача ЖМ, ця особа не мала ніякої категоpiï. Згідно з поданою діаграмою (рис. 1) відомо, що кількість атестованих становила 43 особи, 3 них 13 освітніх перекладачів ЖМ, що становило $30,2 \%$ від загальної кількості. Зазначені перекладачі ЖМ освітньої сфери працювали або мали досвід роботи в професіонально-технічних училищах (2 особи), коледжах (4 особи) й університетах (7 осіб). 3 наступної діаграми (рис. 2) можемо отримати інформацію щодо місця проживання зазначених перекладачів ЖМ, щоб пересвідчитися в географії комунікативного забезпечення навчальних закладів зазначеними фахівцями, які проходили атестацію. Беручи до уваги кваліфікаційну категорію атестованих освітніх перекладачів ЖМ (рис. 3), стає відомо, що 2 особи мали 2 категорію, що становить $15,4 \%$ від кількості освітніх перекладачів ЖМ, 7 осіб мали першу категорію - 53,8\% і 4 перекладачі ЖМ мали вишу категорію - 30,8\%. Якщо брати для порівняння перекладачів ЖМ інших сфер, то вищу категорію мали $13,3 \%$, першу - 63,3\%, другу $-20,0 \%$ і без 
категорії - 3,3\% (рис. 3). Визначаємо відсутність освітніх перекладачів ЖМ, які б мали освітньокваліфікаційний рівень «перекладач ЖМ без категорії», меншу їхню кількість 3 другою категорією та суттєву кількість перекладачів 3 вищою категорією.
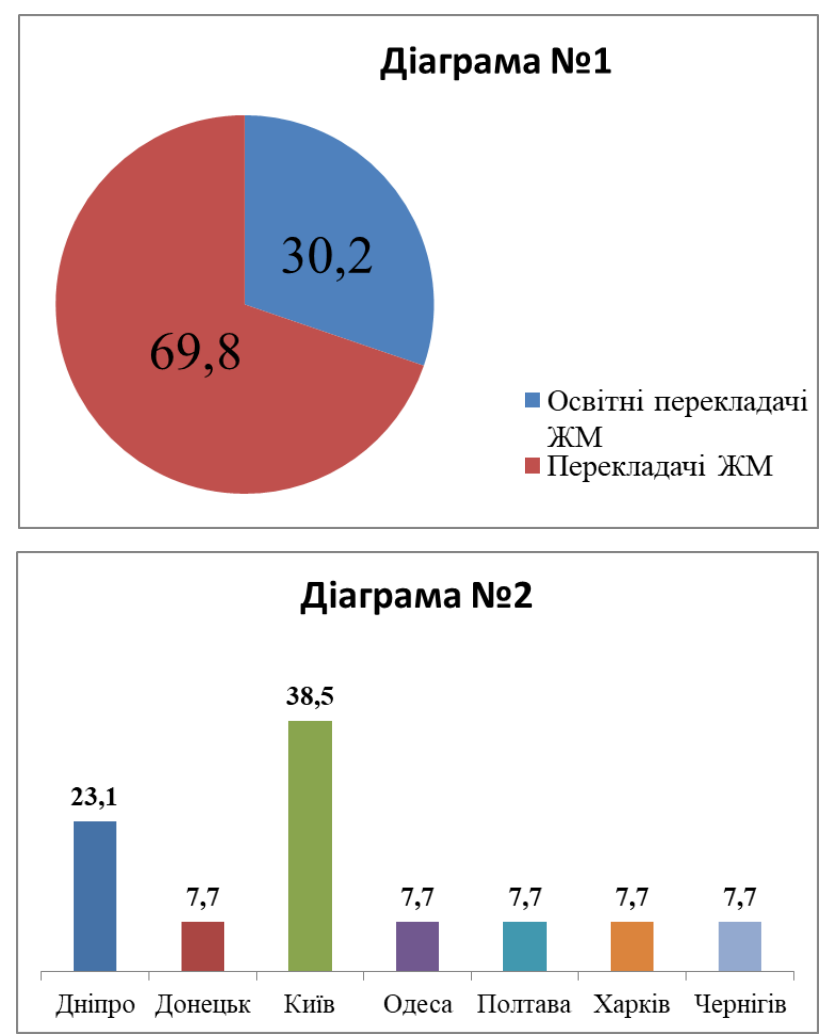

Рис. 2. Географічне проживання атестованих

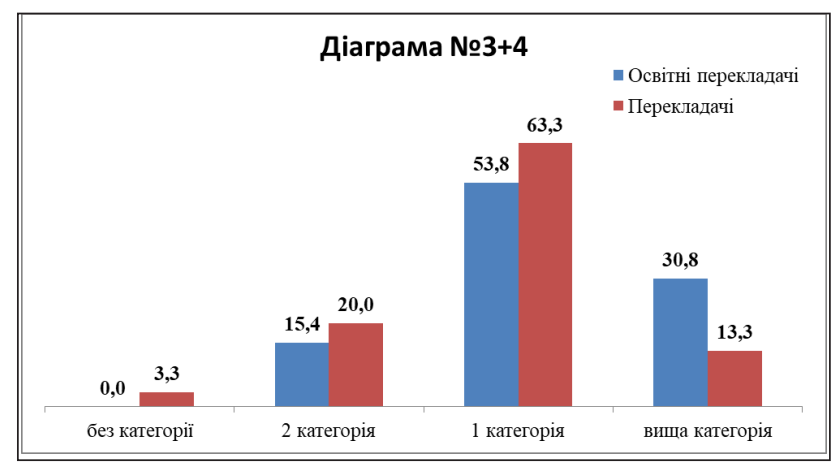

Рис. 3. Освітньо-кваліфікаційні рівні перекладачів ЖМ

Отже, сучасна атестація перекладачів ЖМ проводилася в груповій формі (по 4 особи) за спеціально розробленими завданнями 3 використанням комп'ютерних технологій. Атестовані мали право на часовий проміжок у $60 x 8$ для виконання всіх завдань. Комп'ютерна атестаційна перевірка передбачала кількість спроб і тривалість часу для виконання завдання. Атестаційні завдання були поділені на блоки, які характеризували різні форми й види перекладу між українською мовою та УЖМ і містили наступні напрями перевірки професійних компетентностей [3]:

Блок № 1. Дактилювання:

1) Вправи на перевірку рецептивних навичок 3 артикуляцією та без неї;

2) Вправи на перевірку репродуктивних навичок у супроводі артикуляції та без неї.

Блок № 2. Усно-жестовий переклад:

1) Переклад речення різної складності 3 наступних тем: «Правова», «Медична», «Дозвіллєво-культурна», «Економічна», «Науково-технологічна», «Сільськогосподарська», «Освітня», «Спортивна»;

2) Переклад тексту телевізійних новин.

Блок № 3. Жестово-письмовий переклад:

1) Переклад речень:

a) простої складності, що враховує спокійний темп викладу й загальновживану лексику;

б) вищої складності, що характеризується природним темпом викладу (притаманний переважній більшості глухих) 3 яскравою експресивністю та неологістичними зворотами;

2) Викладення на рисунку схематичних знаків, які зазначені в поданому тексті.

Блок № 4. Письмово-жестовий переклад

1) Переклад поданого речення:

a) КЖм;

б) УЖМ;

2) Переклад тексту, що передбачає використання понять, пов'язаних 3 рухом, напрямом і переміщенням об'єктів у просторі.

Блок № 5. Жестово-усний переклад:

1) Позначення поняття, яке міститься в поданій жестолексемі;

2) Переклад монологічного мовлення;

3) Переклад діалогічного мовлення;

4) Озвучення математичних позначень:

a) числові поняття;

б) математичні дії;

в) числові поняття з різними відношеннями;

5) Переклад тексту, що передбачає використання понять, пов'язаних із рухом, напрямом і переміщенням об'єктів у просторі;

6) Озвучення понять, що містять кольори й відтінки.

Блок №6. Тестування:

1) Перевірка теоретичних знань;

2) Розгляд ситуації.

На основі таблиці № 1 ми можемо отримати такі результати:

- репродуктивні навички (3 блоку № 1) в освітніх перекладачів сформовані відмінно, чого не можна сказати за рецептивні. Це означає, що освітні перекладачі можуть із труднощами зчи- 
Адамюк Н. Інновації оцінювання рівня сформованості професійної компетентності...

тувати дактильне мовлення глухого студента за умови включення його артикуляції; без артикуляції дактильне мовлення глухого студента освітнім перекладачем не сприймається;

- на відміну від усно-жестового перекладу (блок № 2), освітній перекладач ЖМ має труднощі 3 жестово-письмовим перекладом (блок № 3), особливо в частині перекладу завдань вищої складності й викладу схематичного малюнка на основі жестового мовлення;

- письмово-жестовий переклад (блок № 4) в частині перекладу на КЖм дається набагато легше, ніж здійснення перекладу на УЖМ. Гірша ситуація спостерігається в перекладі на ЖМ речень, що містять об'єкти переміщення, руху тощо;

- щодо жестово-усного перекладу, можна констатувати, що числові позначення, математичні дії, числа з різними відношеннями, позначення кольорів та їхніх відтінків не містять тих труднощів, що зафіксовані під час перекладу монологічного мовлення, тексту з об'єктами руху й позначеннями місць, а також, що важливе, перекладу значень жестолексем, які властиві лише УЖМ.

Якщо порівняти результати інноваційного оцінювання за допомогою сучасних комп'ютерних технологій освітніх перекладачів ЖМ у порівнянні 3 перекладачами ЖМ інших сфер надання послуг, то перші знаходяться у виграшній позиції (рис. 4): серед них відсутні перекладачі ЖМ 3 освітньо-кваліфікаційним рівнем «перекладач ЖМ без категорії», більша кількість тих, хто має першу й вищу категорію; водночас $є$ і негативний показник: освітні перекладачі ЖМ з другою категорією переважають перекладачів ЖМ 3 інших сфер надання перекладацьких послуг.

Таблиця 1

Результати оцінювання рівня ЖКК

\begin{tabular}{|c|c|c|c|c|c|c|c|c|c|c|c|c|c|c|}
\hline \multirow{2}{*}{ Блоки із завданнями } & \multicolumn{14}{|c|}{ Освітні перекладачі (13 осіб) } \\
\hline & 1 & 2 & 3 & 4 & 5 & 6 & 7 & 8 & 9 & 10 & 11 & 12 & 13 & \\
\hline \multicolumn{15}{|l|}{ Блок № 1. Дактилювання } \\
\hline Рецептивні навички з артикуляції & 5 & 3 & 1 & 3 & 5 & 5 & 3 & 3 & 5 & 5 & 3 & 3 & 4 & 4 \\
\hline Рецептивні навички без артикуляції & 5 & 1 & 1 & 5 & 5 & 1 & 2 & 2 & 5 & 3 & 1 & 4 & 5 & 3 \\
\hline Репродуктивні навички з артикуляцією & 5 & 5 & 5 & 5 & 5 & 5 & 4 & 5 & 5 & 5 & 5 & 5 & 5 & 5 \\
\hline Репродуктивні навички без артикуляції & 5 & 5 & 5 & 5 & 5 & 5 & 4 & 5 & 5 & 5 & 5 & 5 & 5 & 5 \\
\hline \multicolumn{15}{|l|}{ Блок № 2. Усно-жестовий переклад } \\
\hline Переклад речень різної складності & 4 & 4 & 5 & 5 & 4 & 5 & 5 & 4 & 5 & 4 & 5 & 5 & 4 & 5 \\
\hline Переклад тексту теленовин & 4 & 4 & 5 & 5 & 3 & 4 & 3 & 3 & 5 & 4 & 4 & 5 & 3 & 4 \\
\hline \multicolumn{15}{|l|}{$\begin{array}{l}\text { Блок № 3. Жестово-письмовий } \\
\text { переклад }\end{array}$} \\
\hline Переклад речень простої складності & 5 & 5 & 5 & 5 & 3 & 5 & 4 & 5 & 5 & 3 & 2 & 4 & 3 & 4 \\
\hline Переклад речень вищої складності & 5 & 5 & 4 & 5 & 2 & 5 & 3 & 5 & 5 & 2 & 2 & 4 & 2 & \\
\hline Виклад схематичного малюнка & 5 & 5 & 3 & 4 & 5 & 5 & 2 & 5 & 5 & 3 & 5 & 5 & 5 & 4 \\
\hline \multicolumn{15}{|l|}{$\begin{array}{l}\text { Блок № 4. Письмово-жестовий } \\
\text { переклад }\end{array}$} \\
\hline Переклад речень КЖм & 4 & 5 & 5 & 5 & 4 & 5 & 4 & 3 & 4 & 3 & 5 & 5 & 4 & 4 \\
\hline Переклад речень УЖМ & 4 & 5 & 3 & 3 & 4 & 4 & 4 & 2 & 5 & 3 & 4 & 3 & 3 & 4 \\
\hline Переклад речень зі значенням руху & 3 & 5 & 5 & 5 & 3 & 4 & 3 & 3 & 5 & 3 & 4 & 4 & 4 & 4 \\
\hline \multicolumn{15}{|l|}{ Блок № 5. Жестово-усний переклад } \\
\hline Значення жестолексеми & 4 & 3 & 2 & 4 & 3 & 2 & 3 & 2 & 5 & 2 & 1 & 4 & 3 & 3 \\
\hline Переклад монологу & 4 & 3 & 4 & 4 & 2 & 3 & 1 & 4 & 5 & 2 & 2 & 5 & 3 & 3 \\
\hline Переклад діалогу & 4 & 5 & 1 & 5 & 3 & 5 & 1 & 5 & 5 & 2 & 2 & 5 & 4 & 4 \\
\hline Числові поняття & 5 & 5 & 5 & 4 & 5 & 5 & 5 & 5 & 5 & 5 & 5 & 5 & 5 & 5 \\
\hline Математичні дії & 5 & 5 & 4 & 5 & 3 & 5 & 3 & 5 & 5 & 3 & 2 & 3 & 5 & 4 \\
\hline Числа з різними відношеннями & 5 & 5 & 3 & 5 & 5 & 5 & 3 & 5 & 5 & 5 & 5 & 5 & 5 & 5 \\
\hline Переклад тексту зі значенням руху & 5 & 2 & 3 & 3 & 1 & 4 & 1 & 4 & 5 & 3 & 1 & 3 & 2 & 3 \\
\hline Кольори й відтінки & 5 & 3 & 5 & 5 & 4 & 5 & 5 & 5 & 5 & 3 & 3 & 5 & 5 & 4 \\
\hline \multicolumn{15}{|l|}{ Блок № 6. Тестування } \\
\hline Теоретичні знання з професії & 3 & 5 & 4 & 5 & 3 & 4 & 4 & 3 & 5 & 3 & 5 & 4 & 3 & 4 \\
\hline Розгляд ситуації & 5 & 5 & 5 & 5 & 5 & 5 & 5 & 5 & 5 & 5 & 4 & 5 & 3 & 5 \\
\hline
\end{tabular}




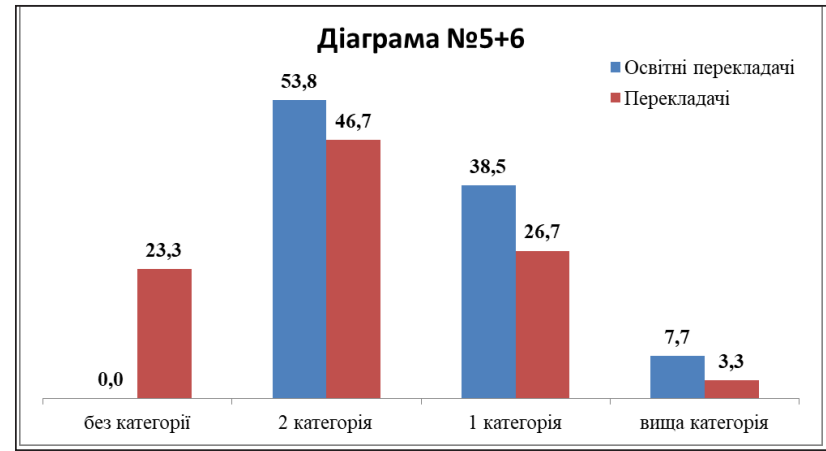

Рис. 4. Результати оцінювання експертами

Таким чином, за результатами оцінювання рівня ЖКК освітніх перекладачів фіксуємо контрастну картину: більшість освітніх перекладачів не відповідає закріпленим за ними категоріям, отриманим на попередній атестації за екзаменаційною формою в паперовому форматі. Наприклад, результати перевірки рівня ЖКК за інноваційною комп'ютерною технологією показали, що на другу категорію склало 7 осіб (раніше ії мали 2 особи); на першу категорію - 5 осіб (раніше їі мали 7 осіб); на вищу - 1 особа (раніше іiі мали 4 особи).

Враховуючи той чинник, що для перекладачів ЖМ, які брали участь в апробації інноваційного оцінювання своєї професійної компетенції вперше, рішенням ЦАК були надані значні бонуси, які мали на меті зберегти за перекладачами ЖМ тарифний розряд і водночас врахувати негативні результати повного неупередженого оцінювання під час навчання перекладачів ЖМ на курсах, семінарах, тренінгах тощо. Таким чином, 3 таблиці результатів апробації оцінювання ЖКК перекладачів ЖМ зникли перекладачі ЖМ без категорії, більшість освітніх перекладачів отримали першу й вищу категорії (рuс. 5).

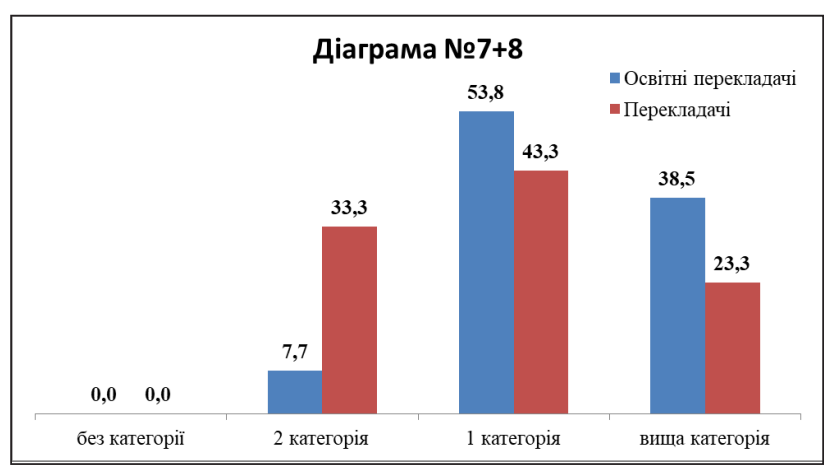

Рис. 5. Результати фактичного присвосння категорії ЦАК

Висновки. Підсумовуючи викладене, зазначимо, що оцінювання професійних компетентностей перекладача ЖМ протягом багатьох десятків років відбувалося за традиційною екзаменаційною формою, і об'єктом перевірки ЖКК перекладачів ЖМ було власне КЖм.

Уперше атестація перекладачів ЖМ здійснюється на основі комп'ютерної програми, яка передбачає блокову систему завдань, що характеризують різні форми й види перекладу між українською мовою та УЖМ і містять різні напрями перевірки професійних компетентностей.

Інновація оцінювання професійної компетентності освітніх перекладачів ЖМ засвідчила низький для роботи в освітній сфері рівень ЖКК, що передбачає зміну змісту форм навчання та підвищення кваліфікації освітніх перекладачів ЖМ.

\section{СПИСОК ВИКОРИСТАНИХ ДЖЕРЕЛ}

1. Адамюк Н. Б. Лінгводидактична модель вивчення лексики УЖМ: аспекти опанування. Особлива дитина: навчання і виховання. 2017. № 1 (81). С. 70-77.

2. Адамюк Н. Б. Особливості вивчення лексики української жестової мови глухими учнями початкової школи : дис. ... канд. пед. наук : 13.00 .03 «Корекційна педагогіка». Київ : Інститут спеціальної педагогіки НАПН України, 2012. $221 \mathrm{c.}$

3. Адамюк Н. Б. Сучасні інноваційні технології оцінювання професійних компетентностей перекладачів жестової мови. Збірник наукових праць «Освіта осіб з особливими потребами: иляхи розбудови». 2016. Випуск 11. С. 16-25.

4. Адамюк Н. Б., Чепчина I. І. Синтаксичні особливості УЖМ: на прикладі простого речення. Жестова мова ц̌ сучасність. 2008. Вип. 3. С. 124-135.

5. Адамюк Н. Б., Дробот О. А., Замша А. В., Федоренко О. Ф. Бімодальний білінгвізм: новий підхід в освіті осіб із порушеннями слуху. Особлива дитина: навчання $і$ виховання. 2019. № 1 (89). С. 35-41.

6. Адамюк Н. Б., Дробот О. А., Замша А. В., Федоренко О. Ф. До проблеми розроблення вітчизняної концепції бімодально-білінгвального підходу до навчання глухих та напівглухих осіб. Науковий журнал «Інноваиійна педагогіка». 2018. Вип. 7. Т. 1. С. 125-130.

7. Брюссельська декларація 2010 року щодо жестових мов Свропейського Союзу (Брюссель, 19 листопада 2010 року.)

8. Про основи соціальної захищеності інвалідів в Україні : Закон України від 11 серпня 2013 р. № 875-XII / Верховна Рада України. URL: http://zakon4.rada.gov.ua/laws/show/875-12/page.

9. Конвенція про права інвалідів : Резолюція генеральної Асамблеї ООН від 13 грудня 2013 р. № 61/106. URL: https://www.un.org/ru/documents/decl_conv/conventions/disability.shtml.

10. Резолюції Свропейського парламенту щодо жестових мов (Doc A2-302/87 від 17 червня 1988 p. i Doc B4-095/98 від 18 листопада 1998 р.). 
11. Стандартні правила забезпечення рівних можливостей для інвалідів: Резолюція Генеральної Асамблеї ООН від 20 груд. 1993 р. № 48/96. Офищиальные отчеты Генеральной Ассамблеи. Сессия 48. Дополнение № 49 (A/48/49). C. 292-306.

\section{REFERENCES}

1. Adamiuk N. B. Linhvodydaktychna model vyvchennia leksyky UZhM: aspekty opanuvannia [A Linguistic-Actual Model for Studying USL: Aspects of Mastering]. Exceptional child: teaching and upbringing, 2017, Vol. 1 (81), pp. 70-77.

2. Adamiuk N. B. Osoblyvosti vyvchennia leksyky ukrainskoi zhestovoi movy hlukhymy uchniamy pochatkovoi shkoly [Features of studying the vocabulary of Ukrainian Sign Language by deaf elementary school students]. PhD thesis. Kyiv : ISP of NAES of Ukraine, 2012 [in Ukrainian].

3. Adamiuk N. B. Suchasni innovatsiini technolohii otsiniuvannia profesiinykh kompetentnostei perekladachiv zhestovoi movy [Modern technology innovation evaluation of professional competence Sign Language interpreter]. Education of persons with special needs: way of development, 2016. Vol. 11, pp. 16-25 [in Ukrainian].

4. Adamiuk N. B., Drobot O. A., Zamsha A. V., Fedorenko O. F. Bimodalnyi bilinhvizm: novyi pidkhid v osviti osib iz porushenniamy slukhu [A Bimodal-bilingual: a new approach in the education of people with hearing impairments]. Exceptional child: teaching and upbringing, 2019. Vol. 1 (89), pp. 35-41.

5. Adamiuk N. B., Drobot O. A., Zamsha A. V., Fedorenko O. F. Do problem rozroblennia vitchyznianoi kontseptsii bimodalno-bilinhvalnoho pidkhodu do navchannia hlukhykh ta napivhlukhykh osib [Issues to development the Ukrainian conception of bimodal-bilingual approach to education of deaf and hard-of-hearing]. Innovative Pedagogy, 2018, Vol 7, Part 1, pp. 125-130 [in Ukrainian].

6. Adamiuk N. B., Chepchyna I. I. Syntaksychni osoblyvosti UZhM: na prykladi prostoho rechennia [Syntactic features of UJM: as an example of a simple sentence]. Sign language and modernity, 2008, Vol. 3, pp. 124-135 [in Ukrainian].

7. Brussels Declaration on Sign Languages in the European Union (2010) [in English].

8. Zakon Ukrainy "Pro osnovy sotsialnoi zakhyshenosti invalidiv y Ukraini", 11.08.2013. - Rezhym dostupu : http://zakon4.rada.gov.ua/laws/show/875-12/page

9. Konventsiia pro prava invalidiv : Rezoliutsiia heneralnoi Asamblei OON № 61/106. - Rezhym dostupu: www.un.org.ua.

10. Rezoliutsii Yevropeiskoho parlamentu shchodo zhestovykh mov (Doc A2-302/87 vid 17 chervnia 1988 roku i Doc B4-095/98 vid 18 lystopada 1998 roku).

11. Standartni pravyla zabezpechennia rivnykh mozhlyvostei dlia invalidiv : Rezoliutsiia Gheneralnoi Asamblei OON vid 20 ghrud. 1993 r. № 48/96 [pereklad ukr. movoiu] // Ofitsiini zvity Gheneralnoi Asamblei, sorok vosma sesiia, Dopovnennia № 49 (A/48/49). - S. 292-306. 